MATEC Web of Conferences 46, 05009 (2016)

DOI: $10.1051 /$ matecconf $/ 20164605009$

(C) Owned by the authors, published by EDP Sciences, 2016

\title{
Experimental study of window-ejected flame and plume on glass curtain walls
}

\author{
Lei Peng and Zhaopeng Ni
}

Tianjin Fire Research Institute of the MPS Tianjin, 300381, China

\begin{abstract}
This research presents an experimental study to investigate the performance of glass curtain walls exposed to exterior flame and plume ejected from windows. A test facility with 3-storey in height was constructed using steel frame to perform full-scale tests. Ventilation-controlled fire scenarios were designed to generate exterior flame and plume ejected from the burning room through a window opening. To characterize potential threats from window-ejected flame and plume to the glass curtain walls of upper floors, temperature, heat flux and air velocity at different heights above the opening upon curtain walls were measured during each test. The effects of window aspect ratio, horizontal projection were studied. It was found that the window with large aspect ratio provided more severe threat to the curtain walls on upper floors. A horizontal projection of $0.5 \mathrm{~m}$ in depth was able to protect the glass on the upper floor from breaking.
\end{abstract}

\section{INTRODUCTION}

As more and more tall buildings are constructed with glass curtain walls, fire safety concern has started to be raised [1]. Most of the building fires are ventilation-controlled. After flashover, flames and hot gases are vented to the exterior of the building, and threaten glass curtain walls above the fire room. Once the temperature of the exterior fire has increased enough or the exterior face of the glass facade has experienced sufficient heat fluxes, the glass curtain wall would break, resulting in the spread of the fire to the upper floor $[2,3]$.

A lot of work has been carried out to investigate the window-ejected flame and plume upon the exterior walls above the opening [4-8]. Correlations were also developed to characterize flame heights, plume temperatures and heat fluxes upon the facade based on a large amount of small-scale tests [4-6]. Although some full scale tests were also carried out [7, 8], the attention of effects of plume temperatures and heat fluxes to the glass curtain walls on the upper floors were not well received.

In glass curtain walls, toughened glass (or tempered glass) are more and more used because of its high strength. When exposed to fire, toughened glass appears to survive higher gas temperatures and heat fluxes than float glass. It was reported that a single-layer of $10 \mathrm{~mm}$ thick toughened glass broke at above $600^{\circ} \mathrm{C}$ [9], and a double-layer of $6 \mathrm{~mm}$ thick toughened glass broke at about $600^{\circ} \mathrm{C}-800^{\circ} \mathrm{C}$ [10]. The breaking temperatures of toughened glass are much higher than those of float glass [11].

This is an Open Access article distributed under the terms of the Creative Commons Attribution License 2.0, which permits unrestricted use, distribution, and reproduction in any medium, provided the original work is properly cited. 


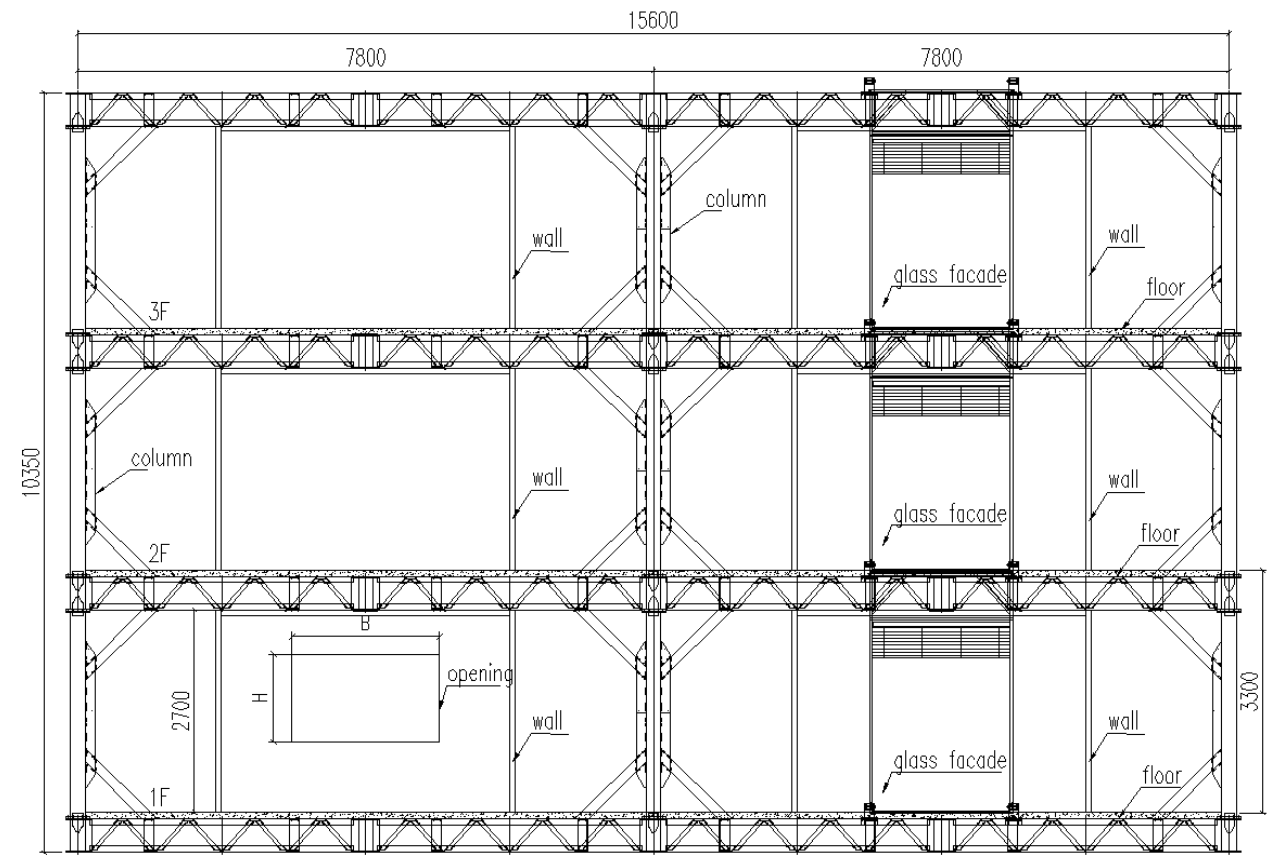

(a) front view

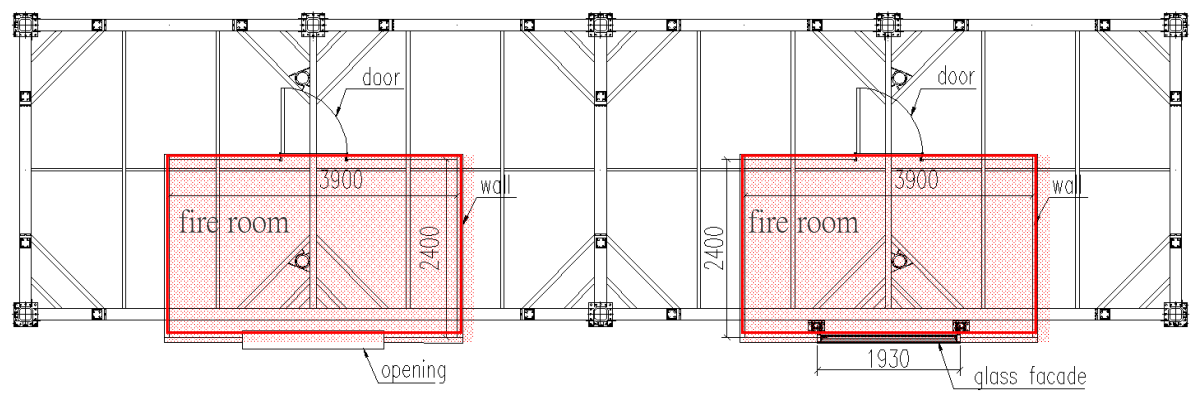

(b) plan view

Figure 1. Schematic of the test frame.

In this research, a series of full-scale tests were carried out to investigate the performance of toughened glass curtain walls exposed to exterior flame and fire plume ejected from windows. Both window aspect ratio and horizontal projection were considered.

\section{EXPERIMENTAL SETUP}

A test facility with 3-storey in height was constructed using steel frames to perform full-scale tests, shown in Fig. 1. The test frame has dimensions of $15.6 \mathrm{~m}$ wide $\times 3.9 \mathrm{~m}$ deep $\times 10.35 \mathrm{~m}$ high. Two testing setups were made on both left and right part of the test frame, using light-frame steel partition walls. Curtain walls could be installed as facade on both sides for testing.

Two identical fire rooms were located on the first floor the test frame. The walls and ceiling were covered with ceramic fibre insulation blanket. The interior dimensions of the fire rooms were $3.9 \mathrm{~m}$ 
$2^{\text {nd }}$ International Seminar for Fire Safety of Facades, Lund (Sweden), 2016

Table 1. Test Scenarios.

\begin{tabular}{|c|c|c|c|c|}
\hline Test \# & Window size $(\mathrm{m})$ & Wood crib weight; wood m.c. & Setup of the exterior wall & Notice \\
\hline 1 & $1.9 \times 1.1$ & $337 \mathrm{~kg} ; 14 \%$ & \multirow{5}{*}{$\begin{array}{c}\text { exterior walls all } \\
\text { covered with fire boards }\end{array}$} & \multirow{3}{*}{$\begin{array}{l}\text { to study effects } \\
\text { of window size }\end{array}$} \\
\hline 2 & $1.4 \times 1.4$ & $349 \mathrm{~kg} ; 15 \%$ & & \\
\hline 3 & $0.9 \times 1.9$ & $354.2 \mathrm{~kg} ; 14 \%$ & & \\
\hline 4 & $1.9 \times 1.1$ & $340 \mathrm{~kg} ; 13 \%$ & & \multirow{2}{*}{$\begin{array}{c}\text { to study effects } \\
\text { of horizontal projection }\end{array}$} \\
\hline 5 & $1.9 \times 1.1$ & $344 \mathrm{~kg} ; 14 \%$ & & \\
\hline 6 & $1.9 \times 1.1$ & $344.4 \mathrm{~kg} ; 14.5 \%$ & \multirow{2}{*}{$\begin{array}{l}\text { glass panel installed } \\
\text { on the } 2^{\text {nd }} \text { and } 3^{\text {rd }} \text { floor }\end{array}$} & \multirow[t]{2}{*}{-} \\
\hline 7 & $1.9 \times 1.1$ & $342 \mathrm{~kg} ; 12 \%$ & & \\
\hline
\end{tabular}

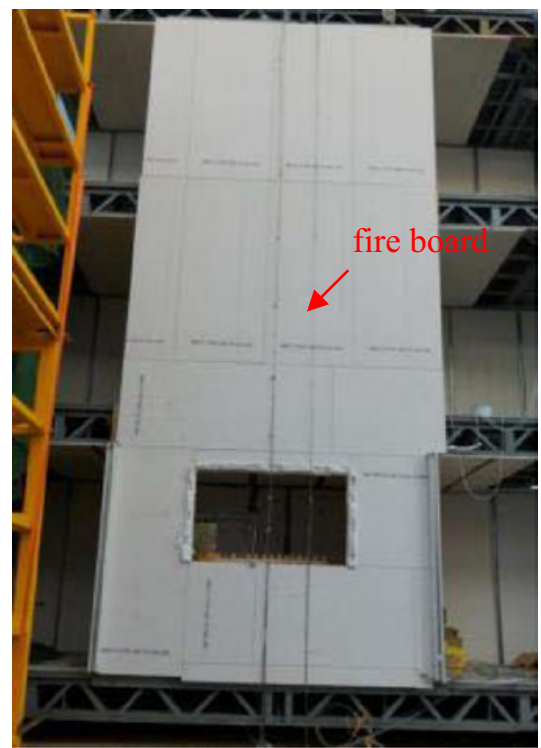

(a) Exterior walls all covered with fire boards

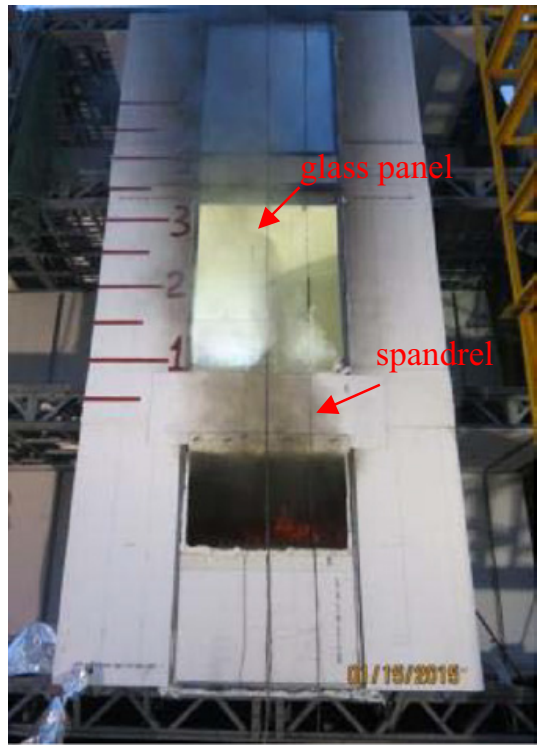

(b) Glass curtain walls installed on the facade

Figure 2. The test frame with facade installed.

Table 2. Window aspects in the tests.

\begin{tabular}{|c|c|c|c|c|}
\hline \multirow{2}{*}{ Test \# } & \multicolumn{2}{|c|}{ Window aspect $(\mathrm{m})$} & Ventilation factor & Maximum heat release \\
\cline { 2 - 3 } & Width & Height & $\sqrt{H}\left(\mathrm{~m}^{5 / 2}\right)$ & $\begin{array}{c}\text { Mate expected }(\mathrm{KJ}) \\
\text { renn}\end{array}$ \\
\hline 1 & 1.9 & 1.1 & 2.2 & 2750 \\
\hline 2 & 1.4 & 1.4 & 2.32 & 2900 \\
\hline 3 & 0.9 & 1.9 & 2.36 & 2950 \\
\hline
\end{tabular}

wide $\times 2.4 \mathrm{~m}$ deep $\times 2.7 \mathrm{~m}$ high. A door was setup at the back of fire rooms to enable installing fire source and instrumentations.

Wood cribs conforming to BS 8414-1 [12] were used as fire source in the research. The cribs were made of pine wood with an average denity of $450 \mathrm{~kg} / \mathrm{m}^{3}$ and an moisture content in the range of $12 \%$ to $15 \%$. The cribs were $1.5 \mathrm{~m} \times 1.0 \mathrm{~m}$ in plane and $1.0 \mathrm{~m}$ high, and had an average weight of $345 \mathrm{~kg}$. The fire load density in the fire rooms was about $36.8 \mathrm{~kg} / \mathrm{m}^{2}$, or $626 \mathrm{MJ} / \mathrm{m}^{2}$ (assuming the heat of combusiton of wood is $17 \mathrm{MJ} / \mathrm{kg}$ ). 


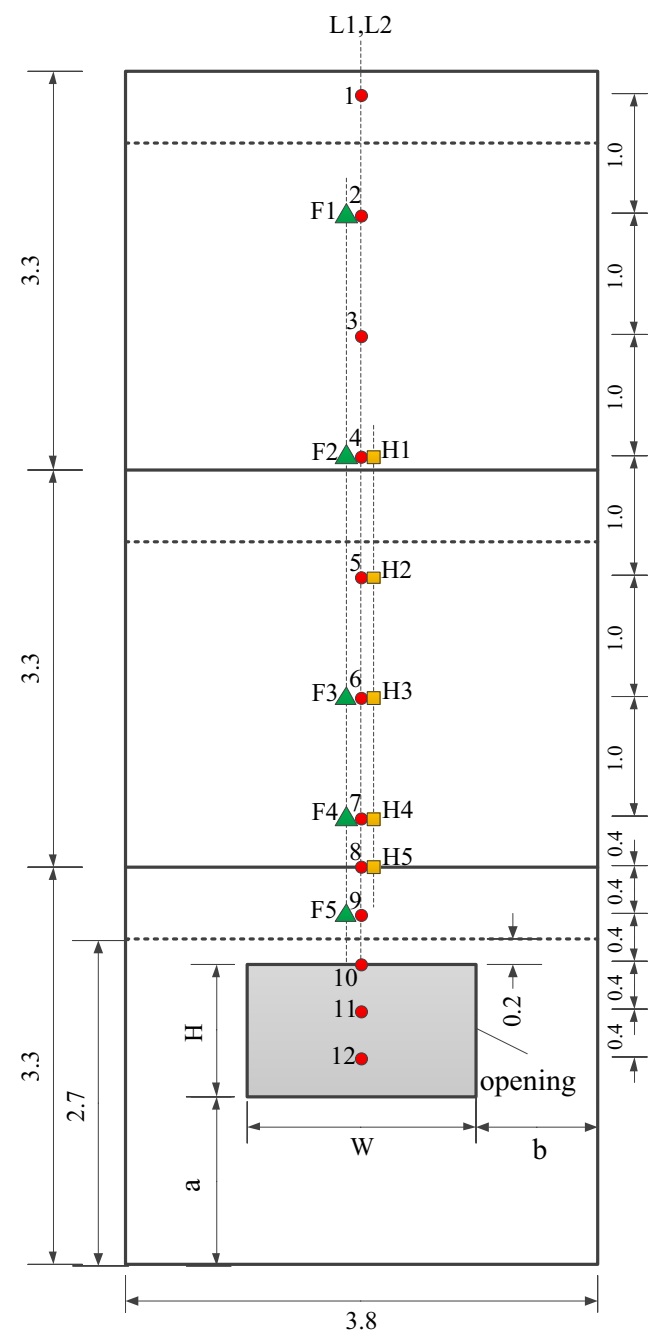

(a) front view
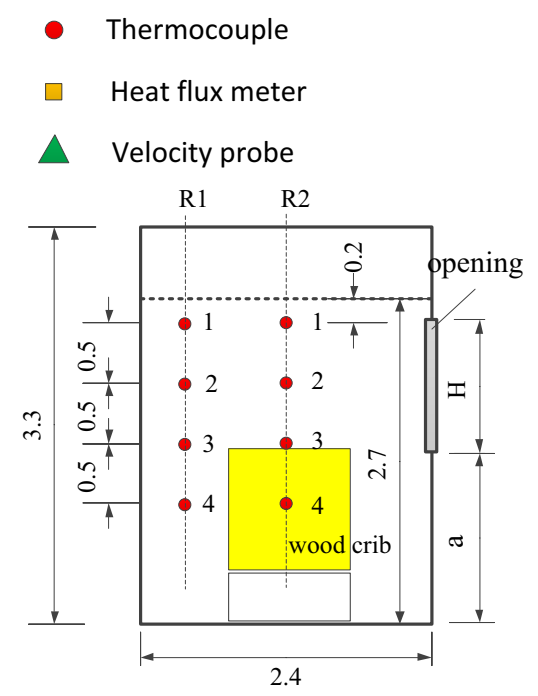

(b) cross-section view of the fire room

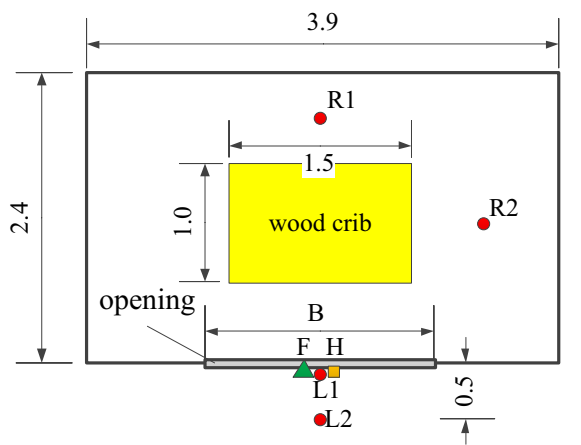

(c) plan view of the fire room

Figure 3. Instrumentations for Test \#1 - \#3.

\section{TEST PROGRAM}

In total, 7 tests were performed, shown in Table 1. The test curtain walls in Test \#1-\#5 were made of light-frame steel studs covered with calcium-silicate fire boards, shown in Fig. 2(a). In Test \#6 and \#7, glass panels were installed on the $2^{\text {nd }}$ and $3^{\text {rd }}$ floor, shown in Fig. 2(b).

The effects of window aspect ratio, horizontal projection were studied. In Test \#1 to Test \#3, three different window sizes were selected to represent typical window types: wide, square and narrow. The windows were supposed to produce similar ventilation factors and maximum heat release rates expected, shown in Table 2. In Test \#4 and \#5, the horizontal projection with $0.5 \mathrm{~m}$ and $1.0 \mathrm{~m}$ in depth at the top of opening were also tested.

The glass panels used in Test \#6 and Test \#7 were steel frame supported and assembled in prefabricated units. Each glass curtain wall unit had a size of $1.9 \mathrm{~m}$ wide $\times 3.3 \mathrm{~m}$ high $\times 0.12 \mathrm{~m}$ thick. 

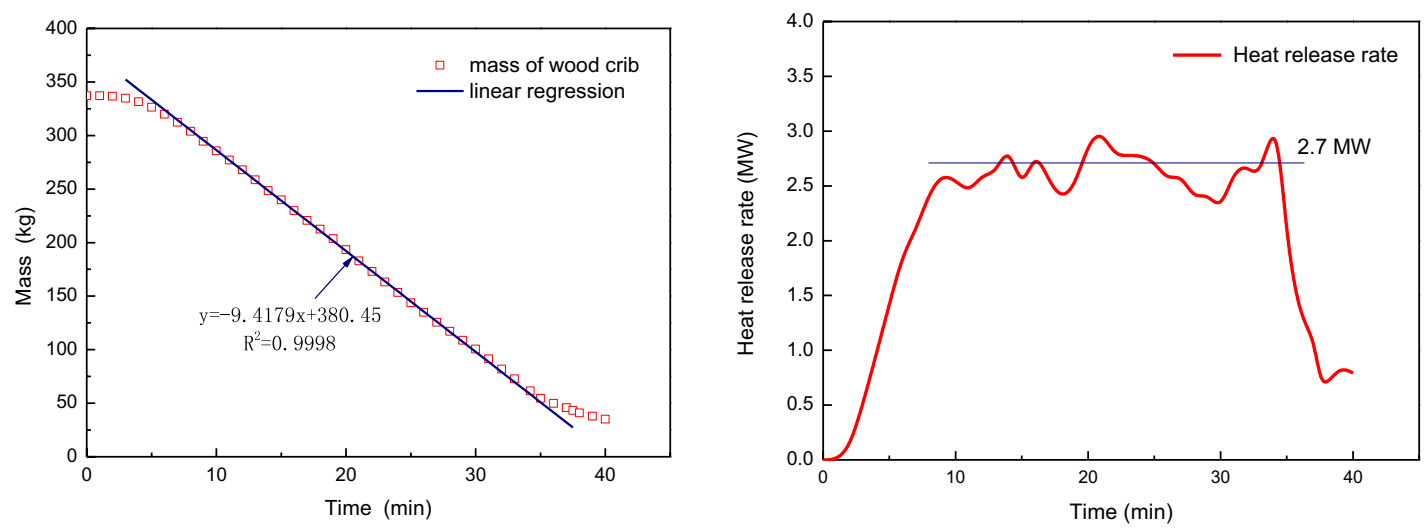

Figure 4. Mass loss of wood cribs and calculated heat release rate in Test \#1.
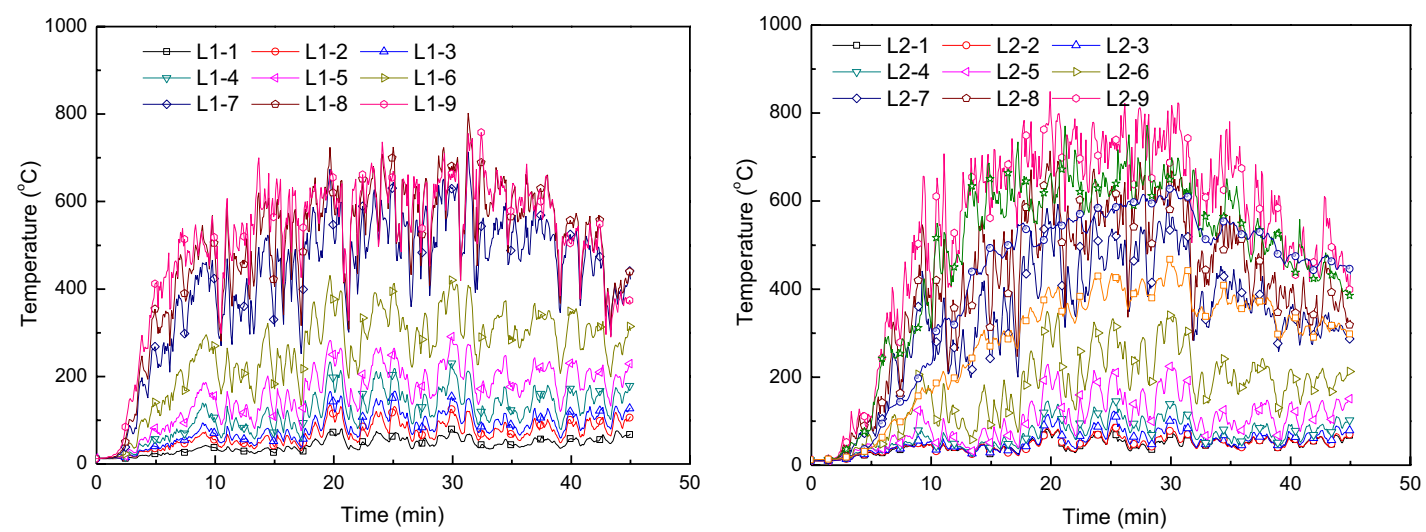

Figure 5. Temperatures of thermocouple tree L1 and L2 in Test \#1.

The unit had 4-layer glass panels. The panels were all made of toughened glass. The outer layer glass was $10 \mathrm{~mm}$ thick, and the inner three layers were $6 \mathrm{~mm}$ thick each. The spandrel height between the window and glass panels was $0.8 \mathrm{~m}$.

\subsection{Instrumentations}

To characterize threats from window-ejected flame and plume to the glass curtain walls of upper floors, temperature, heat flux and vertical gas velocity at different locations upon the curtain walls above the window were measured during tests.

The instrumentation setups in Test \#1 to \#3 are shown in Fig. 3. Despite horizontal projections installed, Test \#4 and \#5 have the same setups of instrumentations as those in Test \#1 to \#3. In Test \#6 and \#7, however, only thermocouples were used to measure the temperatures.

Metal-sheathed and mineral-insulated (MSMI) type K thermocouples (2.0 $\mathrm{mm}$ in diameter) were used to measure temperatures. Two thermocouple trees R1 and R2 were installed in the fire room. R1 was located in the middle of the wood cribs and back wall, while R2 was located in the middle of the wood cribs and left wall. Thermocouple R1-1 and R1-2 were set $0.2 \mathrm{~m}$ beneath the ceiling, and other thermocouples were located $0.5 \mathrm{~m}$ beneath one by one. Two thermocouple trees L1 and L2 were 

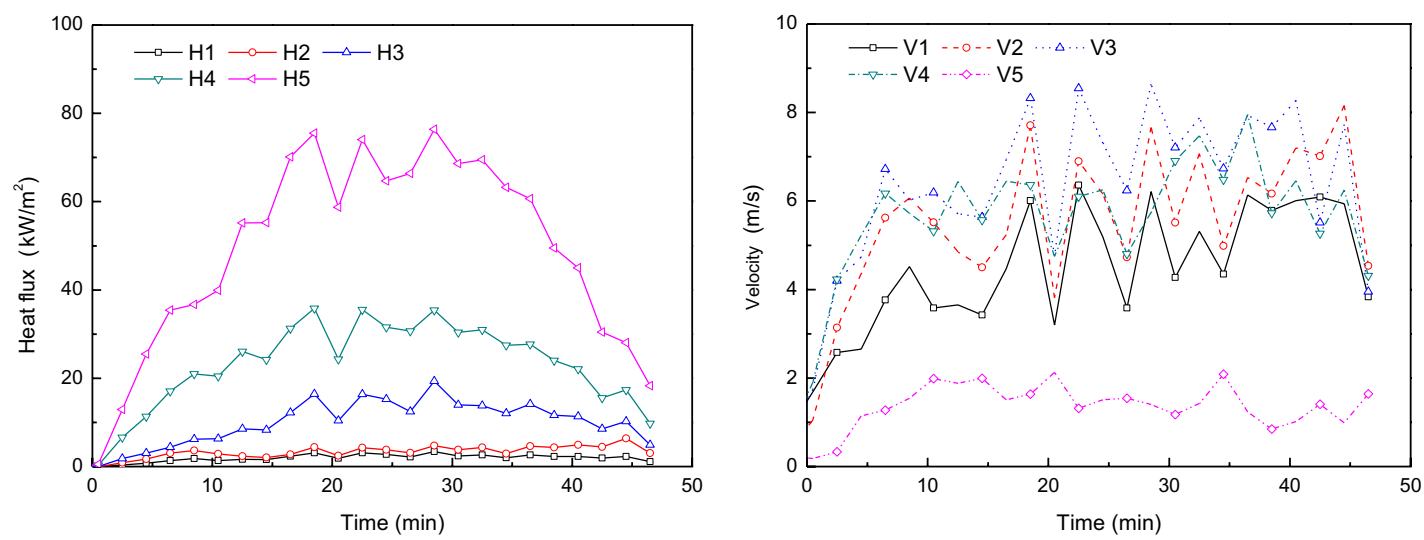

Figure 6. Heat flux and smoke vertical velocity upon the façade in Test \#1.

installed along the central line of the facade. L1 was located close to the facade surface with a distance of $0.05 \mathrm{~m}$, while L2 was located $0.5 \mathrm{~m}$ away from the facade surface. In L1 and L2, the thermocouple \#10 was located at the top of the window opening. The spacing between two thermocouples of \#1- \#7 was $1.0 \mathrm{~m}$, while the spacing between two thermocouples of \#7-\#12 was $0.4 \mathrm{~m}$.

Five Gardon heat flux meters (H1 to H5) were installed along the central line of the facade for Test $\# 1$ - Test \#5. The heights of H1 to H5 above the top of the opening were $4.2 \mathrm{~m}, 3.2 \mathrm{~m}, 2.2 \mathrm{~m}, 1.2 \mathrm{~m}$, $0.8 \mathrm{~m}$, respectively. Five bi-directional velocity probes [13] (F1 to F5) were also installed along the central line of the facade. The heights of F1 to F5 above the top of the opening were $6.2 \mathrm{~m}, 4.2 \mathrm{~m}, 2.2 \mathrm{~m}$, $1.2 \mathrm{~m}, 0.4 \mathrm{~m}$, respectively.

A scale with careful insulation was placed under the cribs to measure the mass loss of the wood during each fire test. Therefore, the heat release rate could be calculated by multiplying the mass loss rate by the heat of combustion of wood.

\section{TEST RESULTS}

As the mass loss was measured during the test, the heat release rate could be calculated. As shown in Fig. 4, the wood cribs generated a steady burning stage over about 30 minutes with an average heat release rate at about 2.7 MW for Test \#1 (assuming the heat of combustion of wood is $17 \mathrm{MJ} / \mathrm{kg}$ ).

The measured temperature profiles of thermocouple tree L1 and L2 are shown in Fig. 5 for Test \#1 as an example. Thermocouple tree L1 was located close to the facade surface with a distance of $0.05 \mathrm{~m}$, while L2 was located $0.5 \mathrm{~m}$ away from the facade surface, as shown in Fig. 3.

The measured heat flux and vertical gas velocity at different heights upon the facade along the central line are also shown in Fig. 6 for Test \#1.

\subsection{Effect of window aspects}

From Test \#1 to \#3, it was observed that the window-ejected flame and plume from wider opening were more likely to move towards the facade above the window opening. As shown in Fig. 7, the attachment of external flame to the facade was observed in Test \#1 (W:B = 1.9); the flame moved very close to the facade but no attachment occurred in Test \#2 $(\mathrm{W}: \mathrm{B}=1)$; the flame ejected away from the facade and no attachment occurred either in Test \#3 (W:B 0.526).

The measured temperature profiles at the central line as a function of height above the top of opening are shown in Fig. 8 for Test \#1 to \#3. Note that L1 was located close to the facade surface with 


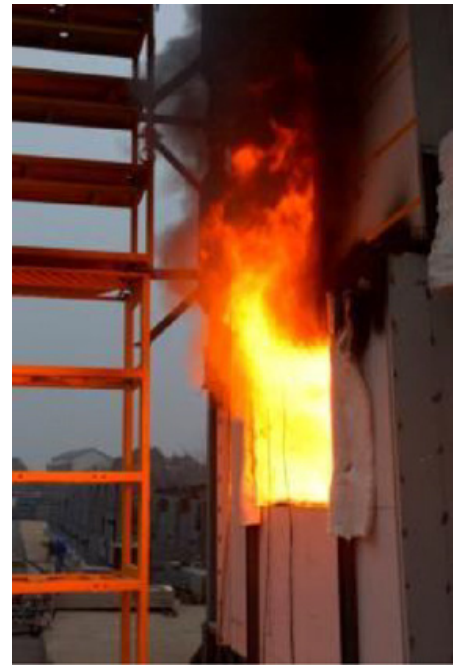

(a) Test \#1

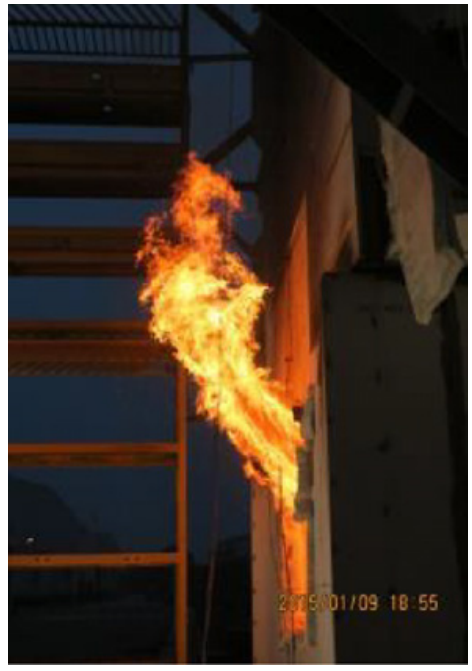

(b) Test \#2

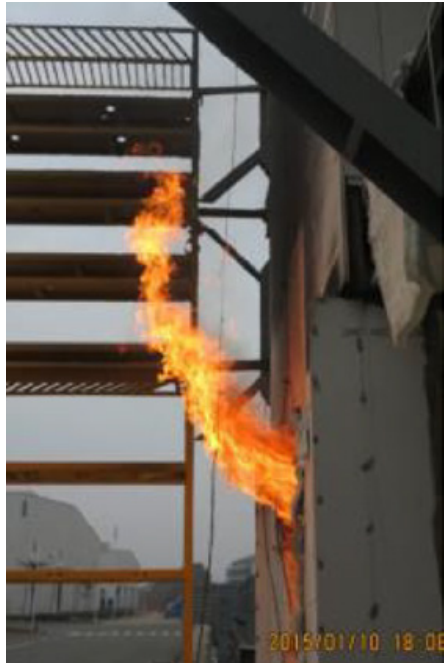

(c) Test \#3

Figure 7. Window-ejected flame upon the facade for Test \#1 to Test \#3.

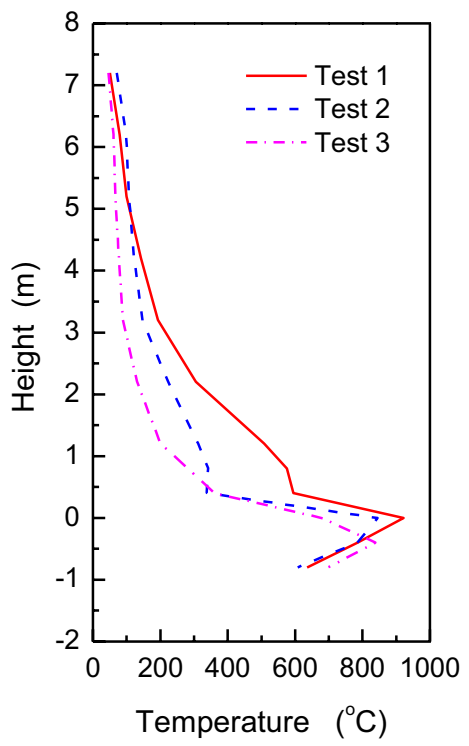

(a) Temperature profiles of $\mathrm{L} 1$

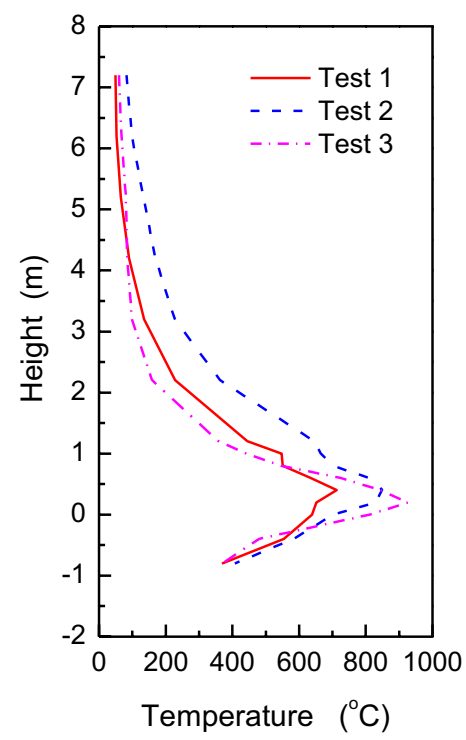

(b) Temperature profiles of L2

Figure 8. Temperature profiles along the central line of facades.

a distance of $0.05 \mathrm{~m}$, while L2 was located $0.5 \mathrm{~m}$ away from the facade surface. It is shown that the temperatures of L1 in Test \#1 are higher than those at the same height in Test \#2 and \#3. This suggests that the flame and plum ejected from wider window opening provide severe threats to the curtain walls on upper floors. 

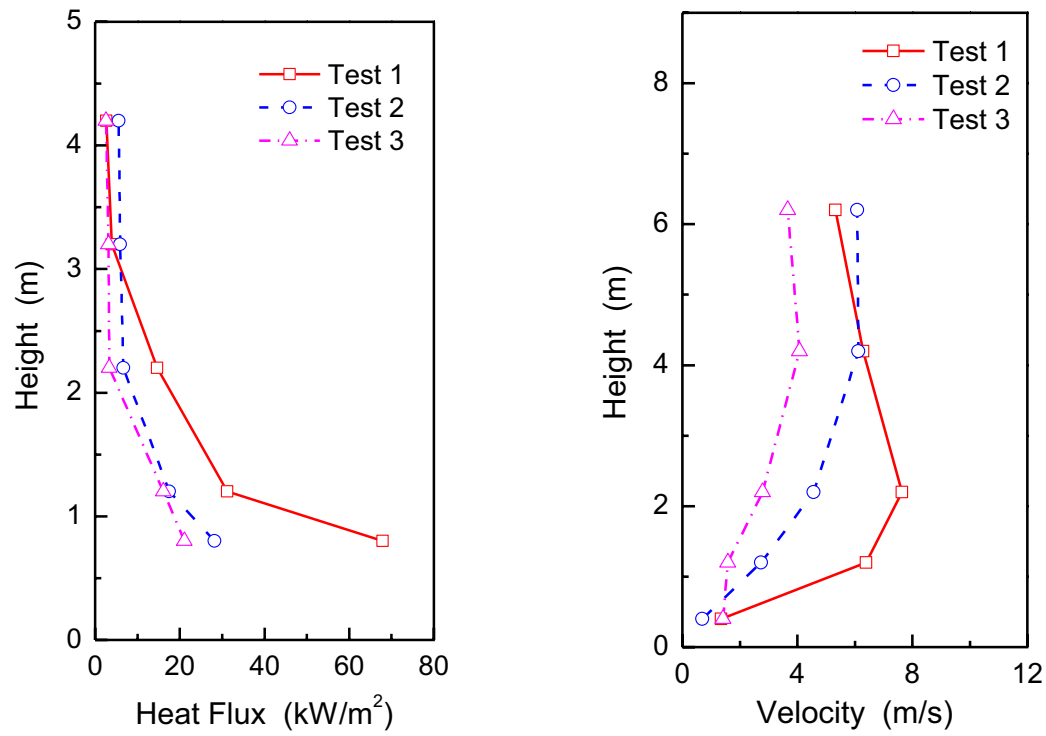

Figure 9. Heat flux and vertical air velocity profiles along the central line of facades.

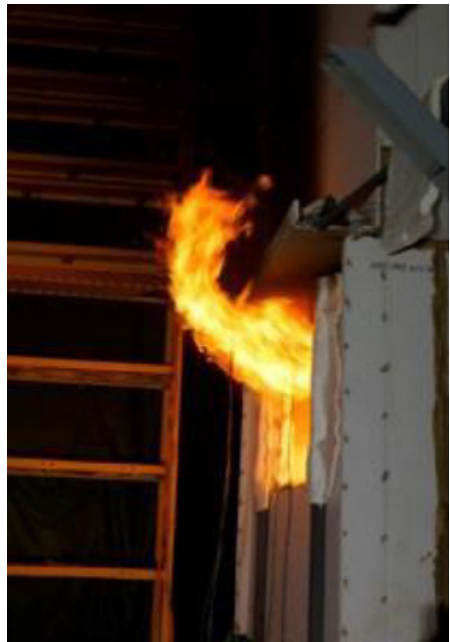

(a) Test \#4

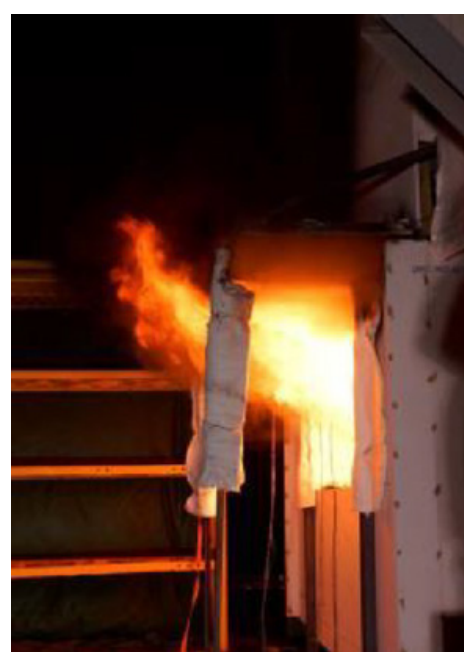

(b) Test \#5

Figure 10. Window-ejected flame upon the facade for Test \#4 and Test \#5.

Figure 9 shows the measured heat flux and vertical air velocity profiles at the central line as a function of height above the top of opening for Test \#1 to \#3. Both heat flux and vertical air velocity were higher in Test \#1 as the opening was wider.

\subsection{Effect of horizontal projection}

Figure 10 shows the ejected flame in Test \#4 and \#5. Due to the effect of horizontal projection, the flame could attach to the facade above the projection. 
$2^{\text {nd }}$ International Seminar for Fire Safety of Facades, Lund (Sweden), 2016

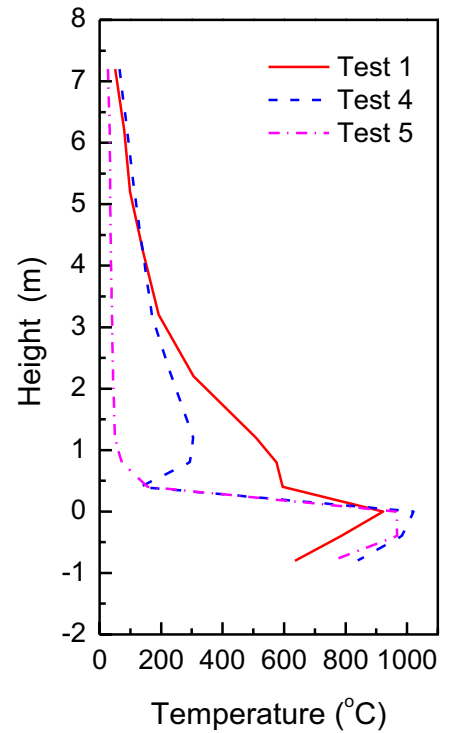

(a) Temperature profiles of $\mathrm{L} 1$

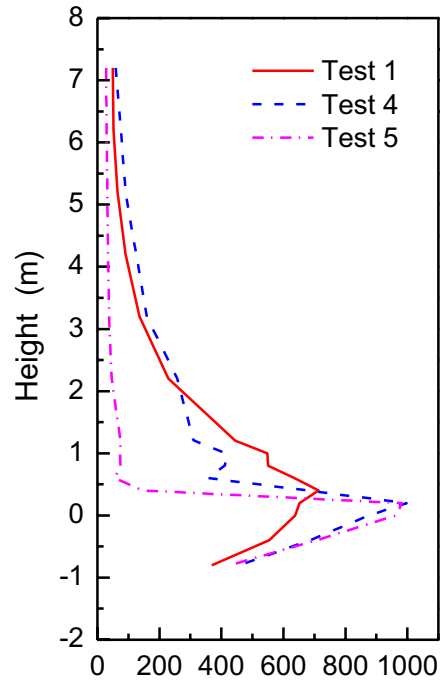

Temperature $\left({ }^{\circ} \mathrm{C}\right)$

(b) Temperature profiles of L2

Figure 11. Temperature profiles along the central line of facades.
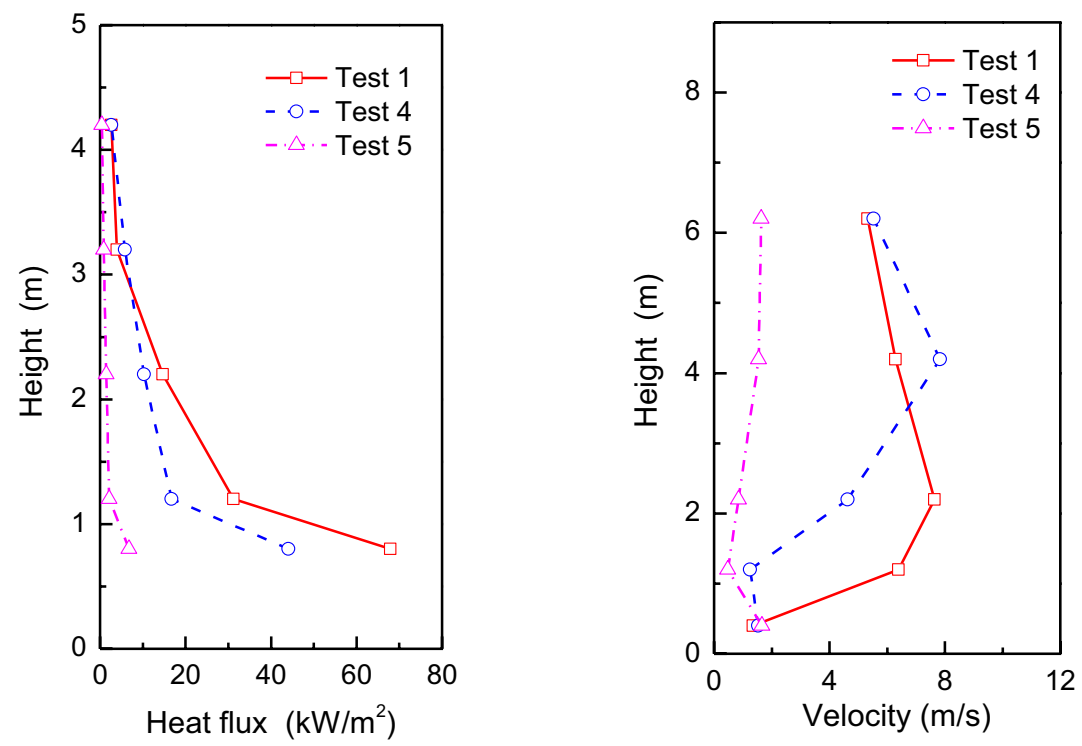

Figure 12. Heat flux and vertical air velocity profiles along the central line of facades.

Figure 11 shows the comparison of temperature profiles at the central line as a function of height above the top of opening for Test \#1, \#4 and \#5. It is shown that as the depth of projection increased, the temperatures of L1 decreased significantly. The maximum temperature at the central line above the projection was about $330^{\circ}$ in Test \#4, while it was about $150^{\circ}$ in Test \#5. A horizontal projection of $0.5 \mathrm{~m}$ in depth was able to protect the glass on the upper floor from breaking. 


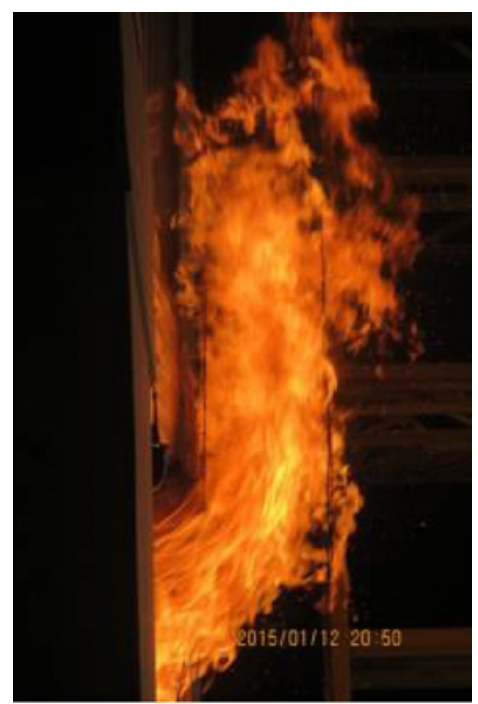

(a) Test \#6

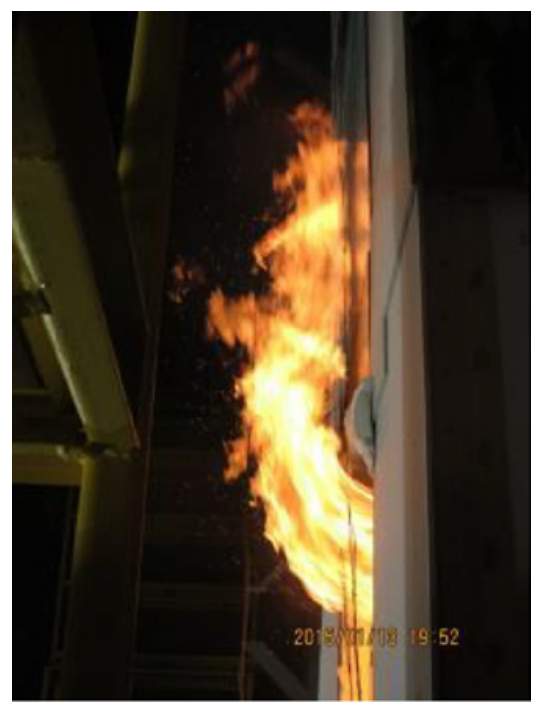

(b) Test \#7

Figure 13. Window-ejected flame upon the facade for Test \#6 and Test \#7.

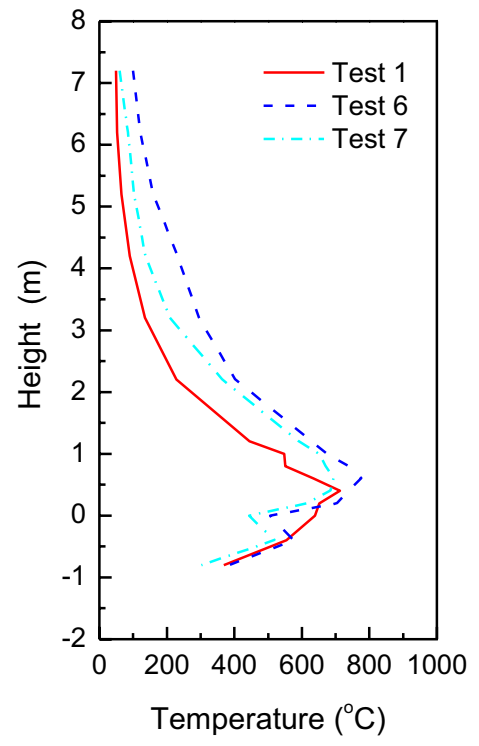

(a) Temperature profiles of L1

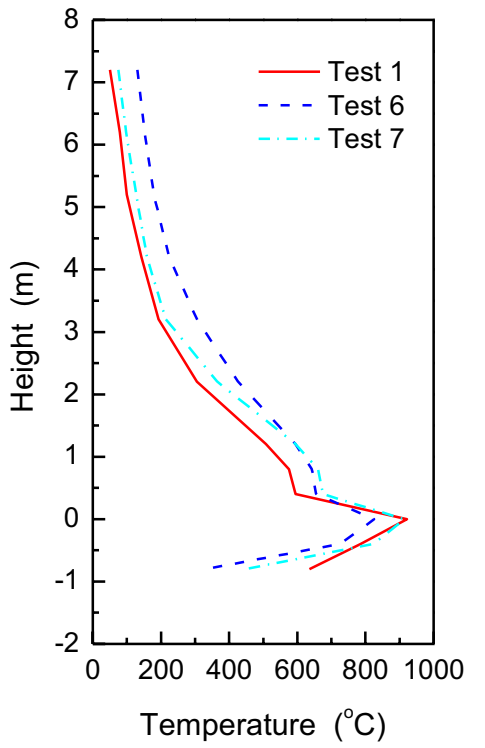

(b) Temperature profiles of L2

Figure 14. Temperature profiles along the central line of facades.

The comparison of heat flux and vertical air velocity profiles at the central line as a function of height above the top of opening is also shown for Test \#1, \#4 and \#5. The heat flux and air velocity profiles confirm that the horizontal projection plays an important role in reducing the threat to the curtain walls on upper floors. 


\subsection{Performance of the glass curtain walls}

It was observed that the breaking of glass panels did not occurred in Test \#6 and \#7. Figure 13 shows that the attachment of flame to the facade above the opening occurred. The spandrel with a height of $0.8 \mathrm{~m}$ successfully prevented the fire spread to upper floors for glass curtain walls made of 4-layer tempered glass.

Figure 14 shows the comparison of temperature profiles at the central line as a function of height above the top of opening for Test \#1, \#6 and \#7. Test \#6 and \#7 had slightly higher temperatures than Test \#1 at the same height. This is probably because the measured maximum heat release rates of Test \#6 and \#7 were slightly higher than Test \#1. Therefore, more heats were discharged in the ejected flame and resulted in higher temperatures. Test \#6 and Test \#7 had similar temperature profiles.

\section{CONCLUSIONS}

Based on the experimental work conducted in this research, the following conclusions can be drawn:

1. The window aspect has an important impact on fire performance of the curtain walls on upper floors. The larger width-height ratio of the window $(\mathrm{B}: \mathrm{H})$, the more likely flame and plume tend to attach to the facade above the opening. This would lead to higher surface temperatures, heat fluxes, and vertical gas velocity upon the facade. As the width-height ratio is close to 1:1, the external flame and plume tend to move apart from the facade, and no attachment to the facade was observed.

2. The horizontal protection above the window also showed its important impact on the fire performance of curtain walls on the upper floors. As the projection depth increased, the temperatures, heat fluxes, and vertical gas velocities upon the facade decreased. When the depth of projection was larger than $0.5 \mathrm{~m}$, no attachment to the facade was observed during the test, and the threats to the curtain walls on upper floors were reduced significantly.

3. Test \#6 and \#7 show that a spandrel with a height of $0.8 \mathrm{~m}$ might be necessary to prevent the toughened glass curtain panels on upper floors from breaking.

This research received supported from the project 2012SJ-A-31 and 2012SJ-A-32.

\section{References}

[1] Chow, C.L., Chow, W.K., Han, S.S., and So, A.K.W. "Vertical air temperature profiles in a single skin glass façade with a 'jumping fire' scenario”, Journal of Applied Fire Science, 17(2), 107-130, 2007-2008,

[2] LPC. "Fire Spread in Multi-Storey Buildings with Glazed Curtain Wall Facades", Loss Prevention Council, Borehamwood, England, 1999.

[3] Xie, Q., Zhang, H., Wan, Y., Zhang, Q., and Cheng, X., "Full-Scale Experimental Study on Crack and Fallout of Toughened Glass with Different Thicknesses", Fire and Materials, 32, 293-306, 2008.

[4] Yokoi, S., "Study on the Prevention of Fire Spread Caused by Hot Upward Current", Report 34, Report of the Building Research Institute, Japan, 1960.

[5] Lee, Y.P., Delichatsios, M.A., and Silcock, G.W.H., "Heat fuxes and flame heights in facades from fires in enclosures of varying geometry", Proc. Combust. Inst., 31, 2521-2528, 2007.

[6] Tang, F., Hu, L.H., Delichatsios, M.A, Lu, K.H., and Zhu W., "Experimental study on flame height and temperature profile of buoyant window spill plume from an under-ventilated compartment fire", Int. J. Heat Mass Transfer, 55, 93-101, 2012. 


\section{MATEC Web of Conferences}

[7] Oleszkiewicz, I., "Vertical separation of windows using spandrel walls and horizontal projections", Fire Technology, 27, 334-340, 1991.

[8] Klopovic, S. and Turan, Ö.F., "Flames venting externally during full-scale flashover fires: two sample ventilation cases", Fire Safety Journal, 31, 117-142, 1998.

[9] Xie, Q., Zhang, H., Wan, Y., Zhang, Q., and Cheng, X. "Full-Scale Experimental Study on Crack and Fallout of Toughened Glass with Different Thicknesses", Fire and Materials, 32, 293-306, 2008.

[10] Ni, Z., Lu S., and Peng, L., "Experimental study on fire performance of double-skin glass facades", Journal of Fire Sciences, 30, 457-472, 2012.

[11] Babrauskas V., "Glass breakage in fires", Issaquah, WA: FireScience and Technology Inc., 2010.

[12] BS 8414-1, "Fire performance of external cladding systems - Part 1: Test method for nonloadbearing external cladding systems applied to the face of the building", 2002.

[13] McCaffrey, B.J., and Heskestad, G., "A robust bidirectional low - velocity probe for flame and fire application", Combustion and Flame, 26, 125, 1976. 